\title{
On the Verbal Complements of Aspectual Verbs
}

\author{
Nikolaos Lavidas ${ }^{\mathrm{a}}$ and Gaberell Drachman ${ }^{\mathrm{b}}$ \\ a) Aristotle University of Thessaloniki, Greece \\ nlavidas@auth.gr \\ b) University of Salzburg, Austria \\ gaberell.drachman@sbg.ac.at
}

\begin{abstract}
This article presents independent morpho-syntactic evidence from Ancient Greek and Old English supporting the existence of two alternative Aspect functional heads (following Fukuda 2007 on Modern Japanese and Modern English). The focus of the study is on the similarities between Ancient Greek and Old (and Modern) English aspectual verbs and on the consequences of these similarities for the analysis of aspectuals. Ancient Greek and Old English aspectual verbs fall into two groups: (a) aspectual verbs that could select both infinitive/to-infinitive and participial/bare infinitive complements (aspectual in H-Asp), and (b) aspectual verbs that selected only a participial/bare infinitive complement (aspectual in L-Asp). No aspectual verb takes only infinitive/to-infinitive. Furthermore, "long middles/passives" is an option only with aspectual verbs in L-Asp, while the regular embedded middle/passive is the only option with an aspectual verb in H-Asp. The similar properties of the Greek and English aspectual verbs, however, historically manifest different developments: English not only retained Old English possibilities (to- vs. bare infinitives), but later extended them from Middle English into the 18th century, while in Greek the development of the infinitive and the participle affected the options of verbal complements of aspectual verbs.
\end{abstract}

Keywords

aspectual verbs; verbal complementation; diachronic syntax; Ancient Greek; diachrony of English

\section{Introduction ${ }^{1}$}

Despite the considerable distance between their structures in so many other areas of language, Ancient Greek and Old (and Modern) English present a remarkably similar set of selectional properties for the aspectual verbs-verbs

\footnotetext{
*) We thank the anonymous reviewers for very helpful suggestions.

1) List of Abbreviations: ACC accusative, ACT active, AOR aorist, CONJ conjunction, DAT dative, FUT future, GEN genitive, GER gerund, IMP imperative, INF infinitive, ING -ing ending (gerundives), IPFV imperfective, MID middle, MP mediopassive, NOM nominative, OPT optative, PFV perfective, PL plural, PRS present, PRT particle, PTCP participle, SG singular, SUBJ subjunctive.

Examples are given a broad phonological transcription (and stress is not marked). As is wellknown, the phonological system of Greek changed significantly during the Hellenistic-Roman 
of commencing, (dis)continuing and completion. Some of these verbs can select both infinitive/to-infinitive ${ }^{2}$ and participial/bare infinitive (gerundive) ${ }^{3}$ complements, while others select only participial/bare infinitive (gerundive) complements. We will show (based on other morpho-syntactic evidence as well) that this dichotomy in Ancient Greek, Old (and Modern) English corresponds to a structural ambiguity between the alternative syntactic positions that aspectual verbs can occupy (H-Asp(ect) position [+ infinitive (to-infinitive) or participle (bare infinitive/gerundive) as complement] or L-Asp(ect) position [+ participle (bare infinitive/gerundive) as complement]). Travis (1991), Borer (1994, 1998, 2005), and Fukuda (2007) have shown that aspectual verbs are functional heads that encode aspectual information about events, while Fukuda (2007) has argued that Aspect heads can occur in two positions.

In the earlier literature on aspectuals, there is consensus that aspectuals involve ambiguity, an ambiguity which has been analysed either (i) as lexical or (ii) as structural ambiguity.

(i) Lexical ambiguity between raising and control structure has been argued in various analyses from Perlmutter's analysis $(1968,1970)$, to case-based (Martin 2001), movement-based (Hornstein 2003), or agree-based (Landau 2004) analyses. The evidence for raising comes from the fact that aspectual verbs can have non-thematic subjects: they allow for expletive subjects (ex. 1a), active/ passive synonymy (ex. 1b), and idiom chunks to maintain their idiomatic meanings (ex. 1c). The evidence for control comes from the fact that subjects of aspectual verbs must be thematic in some cases: an aspectual verb can be embedded under a control verb (ex. 2a), and aspectual verbs are compatible with the imperative (ex. $2 b)$.

(1) raising:

a. expletive subjects

It began to rain.

(Perlmutter 1970:109, (7))

period. For this reason and as details about the phonological system and its changes are not relevant to the present study of syntactic changes, Ancient Greek examples are given a broad classical Ancient Greek transcription, whereas examples of the Modern Greek period are given a broad Modern Greek transcription. For readability the Ancient Greek vowels are presented by transliterating the Greek orthography, not in phonological transcription (cf. Kiparsky 2003): (i) for $\langle\omega\rangle$

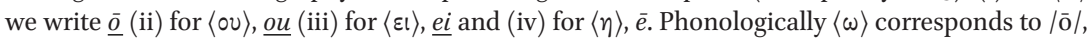
$\langle\circ u\rangle$ corresponds both to $/ \mathrm{ou} /$ and $/ \overline{\mathrm{o}} /,\langle\varepsilon \mathrm{\imath}\rangle$ both to $/ \overline{\mathrm{e}} /$ and $/ \mathrm{ei} /$, and $\langle\eta\rangle$ to $/ \overline{\mathrm{e}} /$. This 'shortcut' is not problematic in the present context since this present study of diachronic syntax does not depend on vowel quality.

2) Infinitive in Ancient Greek, to-infinitive in Old and Modern English. See below on the development of these categories in the respective languages.

3) Participle in Ancient Greek, bare infinitive in Old English (gerundive in Modern English). See below on the development of these categories in the respective languages. 
b. active/passive synonymy

The noise began to annoy Joe.

Joe began to be annoyed by the noise. $\quad$ (Perlmutter 1970:109, (9))

c. idiomatic meanings

Headway began to be made toward a solution. ${ }^{4} \quad$ (Perlmutter 1970:110, (13))

(2) control

a. aspectuals embedded under control verbs

I tried to begin to work.

(Perlmutter 1970:111, (20))

I forced Tom to begin work.

(Perlmutter 1970:112, (23))

b. imperative

Begin to work!

(Perlmutter 1970:113, (25))

The analyses in terms of 'lexical' ambiguity emphasize that (a) aspectuals can have a non-thematic subject but also behave like control verbs (Perlmutter 1970), (b) aspectuals can take a TP that is [+tense, -finite] or [-tense, -finite] (Martin 2001), (c) the landing site of the movement of the subject of aspectuals can be an argument or a non-argument position (Hornstein 2003), and (d) the complement of aspectuals is a CP (embedding an IP with [-T]) or an IP (Landau 2004). All the analyses mentioned above hold the same assumption, namely that the control/raising ambiguity with aspectual verbs would have to be lexical: in other words, whether a given aspectual verb is a raising or a control verb, its structural position is the head of VP, and the differences between control and raising follow from different selectional restrictions.

(ii) According to Fukuda, the control/raising analysis of aspectual verbs appears untenable given that aspectual verbs actually fail to behave as control or raising verbs: aspectuals cannot be raising verbs, since they can have nonthematic subjects but their complements do not contain a tense projection or grammatical/viewpoint aspect projection (the standard assumption being that sentences with raising predicates are bi-clausal, ex. 3a, b); aspectual verbs are not control verbs, since they are compatible with the imperative (ex. $3 \mathrm{c})$.

(3) a. *He began [Progressive being running down the road].

b. *He began [Perfective to have finished his homework].

c. Begin to work!

(Akmajian et al. 1979:40, (112)) (Perlmutter 1970:113, (25))

In order to account for the problematic behavior of aspectual verbs, Fukuda proposed that aspectual verbs are functional heads which appear above and/or below a projection of the Voice head or little v (Kratzer 1994, 1996, Chomsky 1995, among many others). Fukuda called their projection Aspect Phrase (AspP),

\footnotetext{
4) We thank the anonymous reviewer who mentioned that there is disagreement about the synonymy in (1b) and the grammaticality of (1c); we agree that this disagreement is perhaps another argument contra Perlmutter's analysis.
} 
following Travis (1991), and the projection of Aspect above vP H(igh)-Asp(ect), while the one that is below vP $L(o w)$-Asp $(e c t)$. Fukuda argued that this proposal is supported by independent morphological and syntactic evidence: the complement of the aspectual in H-Asp is realised as an infinitival and gerundive complement and the complement of the aspectual in L-Asp is realised as a gerundive complement (in Modern English). Control and raising cannot explain the two different complement types, infinitive and gerundive; the difference in selection of the two complement types is a consequence of the two possible positions for aspectuals in the analysis of Fukuda. Hence, Fukuda (2007) offers an alternative analysis to that of lexical ambiguity; with aspectual verbs we have a case of structural ambiguity between alternative syntactic positions. Assuming Fukuda's analysis, aspectual verbs are heads of functional projections rather than main verbs taking clausal complements, and may occupy two different positions, either above or below $v \mathrm{P}$; aspectual verbs which take either type of clausal complement (as Modern English begin, continue, cease) can appear either in H-Asp (they take infinitives or gerundives as complements) or in L-Asp (they take gerundives as complements). Aspectual verbs that take only a gerundive complement (as Modern English keep, stop, finish) can only be in L-Asp. No aspectual verb only takes infinitives as complements.

(4)

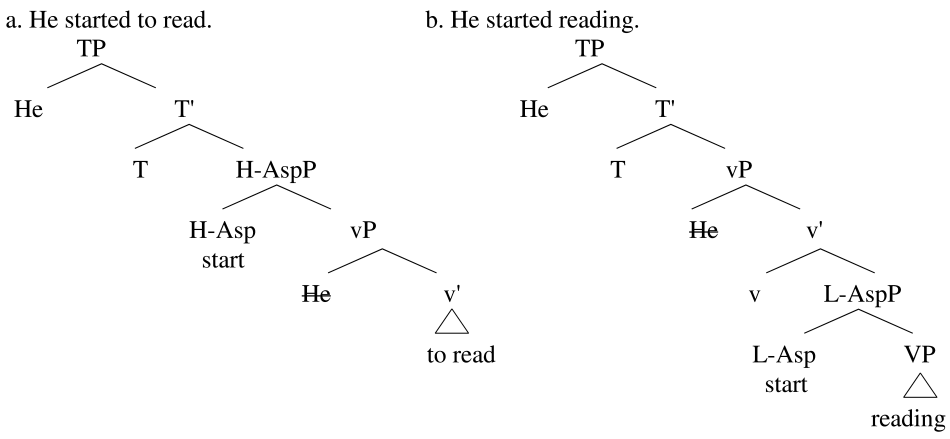

A functional head analysis has been proposed for aspectual verbs in German (Wurmbrand 2001), Romance languages (Cinque 2003), Basque (Arregi \& Molina-Azaola 2004), Japanese (Fukuda 2006), and Modern English (Fukuda 2007): the main evidence for most of these languages is that long passive, i.e. passivisation of an embedded object with the passive morpheme appearing only on the matrix/aspectual verb, is the only option with aspectual verbs in L-Asp, since the passive morpheme is above the position of the aspectual verb, while the regular embedded passive is the only option with an aspectual verb in H-Asp, since the passive morpheme is below the position of the aspectual verb.

For the notion of structural ambiguity, important similarities are also revealed if we compare complex and aspectual verbs; (i) with complex verbs, 
the root-merger with an affix gives idiosyncratic readings, but post-Category (post-Cat) merger with an affix gives compositional readings (Marantz 2001). Contrast, for example, the root-merger in the Modern Greek verb sin-erxome (idiosyncratic 'recover') and the post-Category merger in sin-ipografo (compositional 'countersign') (Drachman 2008); (ii) with aspectual verbs, the merger of the aspectual verb above or below vP appears to result in the distinction between compatibility with infinitive and/or gerundive complements.

In the next section, we will present the Ancient Greek data that supports Fukuda's proposal: aspectual verbs in Ancient Greek fell into two groups, those that could select both infinitive and participial complements and those that selected only a participial complement; "long middles/passives" was an option only with aspectual verbs in L-Asp (+participial), while the regular embedded middle/passive was the only option with aspectual verbs in H-Asp (+infinitive). In turn, Ancient Greek infinitives appear to have been less limited than participles. Finally, we will show that the development of verbal complementation of aspectuals is related to the development of the infinitive and the participle in Greek: their development (loss and replacement by na-clauses or change into gerunds and "adjectives" respectively) did not permit them to remain as an option of verbal complementation of aspectual verbs.

\section{Aspectuals in Ancient Greek and Fukuda's Analysis}

As seen above, Fukuda argues that his proposal is supported by the independent morphological and syntactic evidence of the presence of two different complement types (in Modern English, for example, infinitive and gerundive); the difference in selection of the two complement types should be a consequence of the two possible positions for aspectuals and cannot be explained by a raising and control analysis. ${ }^{5}$

Ancient Greek aspectual verbs fell into two groups as well; (i) aspectual verbs that could select both infinitive and participial complements; (ii) aspectual verbs that selected a participial complement. Most Ancient Greek aspectual verbs belonged to the second group and took a participle as a complement. Less frequent was the use of the infinitive, ${ }^{6}$ in alternation with the participle. Aspectual verbal meaning seems not to play a role in the choice of the complement:

\footnotetext{
5) The presence of additional projections (in the present paper, two Aspect projections, according to Fukuda) in order to explain cross-linguistic (and Greek) data was a tendency that assisted in the analysis of various phenomena in the past — for example, high and low Neg(ation)P.

6) For the Ancient Greek infinitives, cf. Sevdali (2007), where one can find the relevant bibliography as well.
} 
both participles and infinitives could follow a verb meaning 'begin', 'continue', ‘stop' or 'finish'.

(i) Aspectual verbs + infinitive or (active or mediopassive) participle ${ }^{7}$

a. diamenō 'continue'

b. pauō 'stop'

c. pauomai $^{9}$ 'cease'

d. diaprassō 'finish, accomplish' (with infinitive and less frequent with participle)

e. $\operatorname{arkhomai}^{10}$ (less frequent: $\operatorname{arkho}^{11}$ ) 'begin' (frequent with infinitive, but also with participle)

(5) a. ean d' epainein ton heteron arksōmai

if PRT praise.INF.ACT the.ACC other.ACC $\overline{\text { begin.AOR.SUBJ.MID.ISG }}$

'if I begin to praise the other'

(Plato, Phaedrus, 241e, 2)

b. ē pothen an orthōs arksaimetha andras agathous

or how PRT rightly commence.AOR.OPT.MID.IPL men.ACC valiant.ACC

epainountes

praise.PTCP.ACT.NOM.PL

'or how could we rightly commence praising these valiant men'

(Plato, Menexenus, 237a, 1)

The object of an aspectual verb could, in Ancient Greek, also be the subject of the participle: both the participle and its subject are in the accusative case (ex. 6 - and not in the nominative case as in the examples where the subject of the verb is also the subject of the participle, see ex. 7).

7) We present here only an indicative list of aspectual verbs, trying to give equivalents to Modern English aspectuals (mentioned in the literature and mainly in Fukuda) in Ancient Greek. The decision on which Ancient Greek aspectuals are used as equivalents to Modern English aspectuals is mainly based on the Woodhouse's English-Greek Dictionary and the Liddell, Scott, Jones \& McKenzie Greek-English Lexicon (LSJM). The data set is mainly based on published discussions by the authors of other relevant phenomena in the area of transitivity and aspectuals, and is supplemented by examples quoted from other scholars and by data collected from the online version of the Thesaurus Linguae Graecae (TLG): http://www.tlg.uci.edu/. The generalizations (wherever stated) are based on the following grammars of Greek: Goodwin (1894 [1978]), Jannaris (1897 [1968]), Kühner \& Gerth (1898-1904 [1963]), Gildersleeve (1900), Stahl (1907), Smyth (1920 [1956]), Meillet \& Vendryes (1924), Humbert (1945), Schwyzer (1950).

8) pau-ō bears active voice morphology.

9) pau-omai bears mediopassive voice morphology.

10) arkh-omai bears mediopassive voice morphology.

11) $\operatorname{arkh-o}$ bears active voice morphology. 
(6) su nun touton ton andra pauson tauta you.NOM now this.Acc.sG the.Acc.sG man.Acc.sG stop.IMP.2SG these.Acc.PL

poieunta

do.PTCP.ACT.ACC.SG

'stop this man, then, from doing these things'

(Herodotus, 5, 23, 14-15)

(7) ouden pauontai kakotekhnountes

not stop.MP.3PL play-tricks.PTCP.ACT.NOM.PL

'they do not stop playing their tricks' (Demosthenes, Contra Macartatum [Sp.], 2, 3)

(ii) Aspectual verbs + (active or mediopassive) participle

a. diateleō 'continue being or doing so'

b. kartereō 'keep'

c. diagignomai 'continue'

d. lēgō 'cease'

e. eklimpanō 'cease' ${ }^{\prime 2}$

f. eklēgō 'cease'

with mediopassive participle

(8) oupote lēgei kinoumenon

never cease.PRS.3SG move.PTCP.MP.NOM.SG

'it never ceases to move'

(Plato, Phaedrus, 245c, 8)

with active participle

(9) eut'an phlegōn aktisin hēlios khthona lēksēi when.PRT illumine.PTCP.ACT.NOM.SG beams.DAT sun.NOM earth.ACC cease.AOR.SUBJ.3SG 'when the sun had ceased to illumine the earth with his beams'

(Aeschylus, Persae, 364-365)

Note that a tendency can be observed with regard to the voice of the aspectual verb: for example, the verb pauo (active voice) [that belongs to the first group of aspectuals] can take an infinitive or a participle as its complement; while pauomai (mediopassive voice) appears to select a participle as complement. This distribution accords with Fukuda (2007), who has shown that aspectual verbs in the passive should be more natural with aspectuals in L-Asp (+participials)

12) We have not included ekleipō in our indicative list, given it seems that most of the uses of ekleipō do not involve any of the basic aspectual meanings we are dealing with (start-continue-stop). According to the LSJM, its main meanings are: (i) leave out, pass over; (ii) forsake, desert, abandon; (iii) fail; (iv) die; (v) faint; (vi) cease: but mostly as intransitive, and only in few cases with a Participle; (vii) fail; (viii) remain; (ix) depart. 
than with aspectuals in H-Asp (+infinitives). According to the Liddell, Scott, Jones \& McKenzie Greek-English Lexicon (LSJM) (1996), the participle is more often used with pauōpauomai (active and mediopassive) than the infinitive, but we have to note that the LSJM does not compare the mediopassive with the active $p a u \bar{o}$ with respect to their complements. The tendency we mentioned is the following: (a) if the aspectual verb pauō is mediopassive (pauomai), then the complement is participial; (b) if the aspectual verb pauo is active, then the complement is infinitival or participial. Hence, we agree with the remark in the LSJM that participles are more often attested with pauō/pauomai, but perhaps this is due to the fact that participles can be selected by both active and mediopassive pauō. More examples demonstrating the tendency described are given in the Appendix (part (a)). ${ }^{13}$

The above remark is connected to the argument that long passives support structural ambiguity. According to Fukuda, if there are two different Asp heads (above and below v), long passive (passivisation of an embedded object with the passive morpheme appearing only on the aspectual verb) would be the only option with aspectual verbs in L-Asp (the passive morpheme is above the position of the aspectual verb). The regular embedded passive would be the only option with aspectual verbs in H-Asp (the passive morpheme is below the position of the aspectual verb). In Greek the movement (internal merge) of the verb to $\mathrm{T}^{14}$ differentiates the argument of "long passives" in that we expect that the "long passive" can be one (but — since the verb moves to T-not the only) option with aspectual verbs that take a participial (10b). Even a double marking of both the aspectual verb and the participial complement would be possible since the participle is merged below v/Voice. But infinitive complements (with the aspectual verbs in H-Asp [above v/Voice] and then to T; 10a) do not permit the presence of "long passives". Mediopassive morphology can appear with these aspectuals only in the case that they are deponents.

13) Since it is outside the aims of the present paper to have a quantitative analysis of aspectual verbs in the diachrony of Greek and English, the relevant examples of pauō/pauomai + PTCP or INF are collected from the LSJM and the online version of the Thesaurus Linguae Graecae $(T L G)$.

14) Whatever features it has in different periods. 
$(10)$

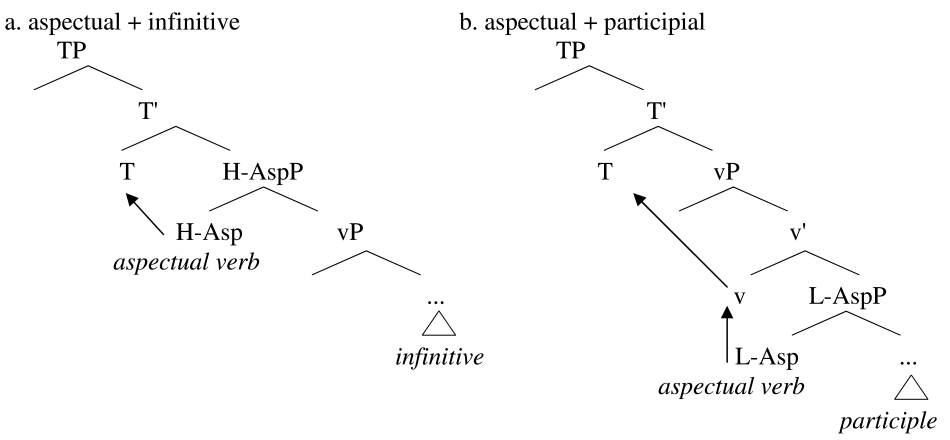

According to the LSJM, most verbs of the second group do not alternate between active and (with middle meaning) mediopassive morphology, just as they do not alternate between the types of their verbal complements (only participial complement). For example, diateleo 'continue being or doing so' always bears active morphology and can have active or mediopassive participial complements.

(11) active diateleo + active or mediopassive participle

On the other hand, verbs of the first group alternate between active and mediopassive morphology and between participial and infinitival complements. With infinitive, the "long passive" (mediopassive morphology in the aspectual verbs instead of the verbal complement) is excluded except for the case of deponent aspectual verbs. For example, arkhomai is only mediopassive (deponent) with the meaning of 'begin' in Classical Greek and has the option of taking infinitival and participial complements. In Homeric Greek (see Appendix, part (b)) the active $a r k h \bar{o}$ was available (with the meaning 'begin') but "long passive" was not attested. Hence, aspectuals of the first group that can bear active morphology (and are not deponents) can take the mediopassive morphology instead of their verbal complement ("long passive"). A type of double marking of the mediopassive morphology is also attested, since the participial complement can be mediopassive as well.

(12) Patterns of the verbal complementation of arkhō/arkhomai

a. Homeric Greek: active $a r k h \bar{o}+$ active or mediopassive infinitive / active participle

b. Classical Greek: deponent mediopassive arkhomai + active or mediopassive infinitive / active participle

c. Classical Greek: deponent mediopassive arkhomai + mediopassive participle.

(13) Generalisation for aspectuals and "long passive" in Ancient Greek:

a. +Infinitive (aspectual in H-Asp): *mediopassive aspectual ("long passive") + infinitive (mediopassive aspectuals with an infinitive are possible only in the case of deponent aspectual verbs)

b. +Participle: mediopassive aspectual ("long passive") is possible (and even the double marking [mediopassive aspectual + mediopassive participle] is possible) 
We must remark that the interpretation of the Ancient Greek mediopassive aspectuals is not passive but middle in the sense that in the specific construction we have absorption of the benefactive argument (with the middle interpretation: the verbal action affects/concerns the subject) ${ }^{15}$ and not of the theme argument. This means that the constructions with mediopassive aspectuals (of course, we do not refer to deponent mediopassive aspectuals here) should be better not called "long passives" in Ancient Greek but "long middles". ${ }^{16}$ Mediopassive aspectuals have a middle meaning, and the middle/mediopassive morphology is marked on the aspectual verb instead of the embedded verb:

(14) a. pauontai legontes stop.MP.3PL speak.PTCP.ACT.NOM.PL

instead of:

b. pauousin legomenoi stop.ACT.3PL speak.PTCP.MP.NOM.PL

'they stopped speaking about their own cases/for their own benefit'

With regard to other tests for aspectual complementation that can be applied to historical data ${ }^{17}$ and other type of evidence (in favour of the hypothesis on the presence of both H-Asp and L-Asp), Ancient Greek infinitives appear to have a less limited range of possible interpretations ${ }^{18}$ than Ancient Greek participles. ${ }^{19}$ (a) Infinitives can be used after almost any verb that requires another verb to

15) Cf. Smyth (1920[1956]: 107): "the middle usually denotes that the subject acts on himself or for himself [amunomai: defend myself / ward off for myself]", Smyth (1920[1956]: 393): "the active is used for the middle when it is not of practical importance to mark the interest of the subject in the action", and Joseph (2001): "middle is used to mark actions that a subject performs on him- or herself (e.g. reflexives), or for his or her own benefit, though in some instances, especially verbs which have only middle voice forms (so-called "deponent" verbs), such as ergazomai 'I work' [...] middle voice seems to be simply a different inflectional class".

16) Assuming that mediopassive has the same syntactic position as passive.

17) Because of the impossibility of testing various characteristics and interpretations with native speakers.

18) Cf. Sevdali (2007) who argues (a) that all infinitives in Ancient Greek are CPs, and (b) that there is a split between two types of CPs, normal $C^{*} \mathrm{Ps}$ (strong phase) that have a contrastive focus feature and Control infinitives that do not have this feature and consequently do not have availability of accusative for the infinitival subject.

19) That is similar to the analysis of gerundives of Modern English as more limited than infinitives with respect to a range of possible interpretations (Bolinger 1968, Freed 1979, Brinton 1988, Fukuda 2007). In English, states are natural with infinitives but often unnatural with gerundives. Further, infinitives can have a "series of events" reading, while gerundives force a "single event" reading.

(1) a. The problem ceased to exist/*existing

b. That never ceases to amaze/??amazing me. 
complete its meaning (Smyth 1920 [1956]: §1990) and may be the only object, or one of two expressed objects of the main verb, while participles can only in some cases be like infinitival complements (Smyth 1920 [1956]: §1850, 2094). (b) But even in the case that a participle can appear instead of an infinitive, infinitives and participles differ greatly. In the case of arkhomai 'begin', for example, if the complement is a participle, the interpretation is 'begin to do something and continue with something else' (single event interpretation ${ }^{20}$ ), while if the complement is infinitive, the interpretation is 'begin to do something and continue with the same thing' (a reading in which the same event is repeated multiple times is allowed) (Smyth 1920 [1956]: § 2128).
a. arksomai
didaskōn
ek tōn theiōn
begin.FUT.MID.ISG teach.PTCP.ACT.NOM.SG from the divine
'I will begin teaching with things divine' (later the topic is the desire for wealth)

(Xenophon, Cyropaedia 8, 8, 2)

b. pothen ērksato se didaskein tēn stratēgian?

whence began.MID.3SG you teach.INF.ACT the generalship

'at what point did he begin to teach you generalship?' (Xenophon, Memorabilia 3, 1, 5)

In the case of pauo 'stop', a participle gives the interpretation 'stop what is taking place', while an infinitive gives the interpretation 'prevent something from taking place' (Smyth 1920 [1956]: § 2140).
(16) a. epausan phoboumenous plēthos neōn ... stopped.ACT.3PL fear.PTCP.MP.ACC.PL multitudes ships 'they stopped being afraid of the multitudes of ships ...'

(Plato, Menexenus, 241b, 6)
b. pausas humas ksenikoisi logois mē lian eksapatasthai prevent.PTCP.ACT.NOM.SG you.ACc alien.DAT words.DAT not much deceive.INF.MP 'by stopping you from being so much deceived by alien words'

(Aristophanes, Acharnians, 634)

\begin{abstract}
20) We leave the further examination of the contrast between bounded vs unbounded events (which is difficult to carry out only on the basis of the written data of Ancient Greek) open for future research. So, we will not use the test of bounded-unbounded events here, but see Cinque (2003) and Fukuda (2007) for data from modern languages. Cinque has shown that the Modern Italian aspectual verb initiare 'start' allows long passive if the event is bounded (presence of quantified object) but not if the event is unbounded (bare object):
\end{abstract}

(1) a. Furono iniziate a construire solo due case

'Only two houses started to be built.'

b. *Furono iniziate a coustruire case

'Houses started to be built.'

Fukuda has argued that with Modern Japanese aspectuals, the only aspectual that must occur in the lower position (oe 'finish') is the one that requires an accomplishment event or a bounded event. 
(c) Furthermore, aspectuals can take an infinitive with a definite article as their complement, but a participle with a definite article as a complement of an aspectual verb is not attested. After verbs meaning 'hinder, prevent, stop', only infinitives allow the presence of an article (Smyth 1920 [1956]: § 1392, 2744); simple infinitives, however, are more closely connected with the main verb than infinitives with to $m \bar{e}$ 'DEFINITE ARTICLE + NEGATION' or to $m \bar{e}$ ou 'DEFINITE ARTICLE + NEGATION + NEGATION'.
a. pausantes
to
mē proselthein stopped.PTCP.ACT.NOM.PL the.ACC not come.INF
engus tēn holkada near the merchantman 'preventing the merchantman from drawing near'

b. *pausantes to mē proselthon

stopped.PTCP.ACT.NOM.PL the.ACC not come.PTCP.ACT.ACC.SG near the

holkada

merchantman

unattested with a similar interpretation, i.e. verbal complementation: 'preventing the merchantman from drawing near'

Both the Ancient Greek participial and infinitive complements of aspectuals changed into Modern Greek na-clauses. Aspectual verbs in Modern Greek appear to take a $n a$-clause ${ }^{21}$ as a complement independently of their meaning ('begin'- 'continue'-'stop'). The presence of a na-clause is blocked only in the case of the verb teliono 'end'.

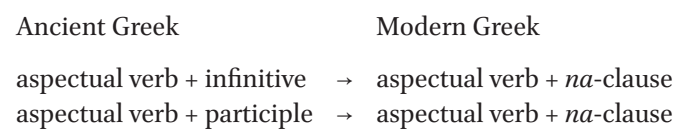

$n a$-clauses with aspectuals have been considered ambiguous between control and raising predicates (Drachman 1989, Alexiadou \& Anagnostopoulou 1999, Tapio 2003). With regard to Modern Greek gerunds, since gerunds are adverbials in Modern Greek (cf. Tsimpli 2000), a DP-direct object for the aspectual verb is very often implied (cf. examples 2ob, 21b).

21) Inasmuch as the focus of the study is on the similarities between Ancient Greek and Old (and Modern) English aspectual verbs and on the consequences of these similarities for the analyses of aspectuals, we do not discuss Modern Greek and the syntactic characterisation of na in Modern Greek at all. Different analyses have been proposed: $n a$ as the head of a MoodP (PhilippakiWarburton 1985, 1993, 1998, Philippaki-Warburton \& Veloudis 1984, Tsimpli 1990, Terzi 1992, Giannakidou 1998) or a ModalP (Rivero 1994); $n a$ as a complementiser $C^{\circ}$ (Agouraki, 1991, Tsoulas, 1993, 1996); $n a$ as both a mood particle and a complementiser (Roussou 200o). 


\section{+ na-clause vs. gerund}

(19) arxise/sinexise na grafi / *na grapsi

started/continued.3SG NA write.IPFV.3SG / NA write.PFV.3SG

's/he started/continued writing'

(20) a. *arxise/sinexise grafondas dio stixus ${ }^{22}$

started/continued.3SG write.GER two.Acc verses.ACc

with the meaning: 's/he started/continued writing two verses'; the sentence is grammatical only with the meaning: 's/he started/continued (her/his day) by writing two verses'

b. arxise/sinexise ti logotexniki zoi tu grafondas

started/continued.3SG the.ACc literary.ACC life.ACC his write.GER

piimata

poems.ACC

'He started/continued his literary life by writing poems'

c. Panda arxizi ta mathimata me to na zografizi kati

always start.PRS.3SG the.ACC classes.ACC with the NA draw.IPFV.3SG something

ston pinaka

on-the blackboard

'He always starts his classes by drawing something on the blackboard'

\section{+ na-clause}

(21) a. stamatise na grafi / ??na grapsi

stopped.3SG NA write.IPFV.3SG NA write.PFV.3SG

's/he stopped writing' (the perfective type is possible only with the meaning: 's/he stopped (sth.) in order to write ...')

b. *stamatise grafondas

stopped.3SG write.GER

's/he stopped by writing'

only in a sentence such as:
stamatise to thimo tu grafondas ena kimeno
stopped.3SG the.ACc anger.ACc his write.GER one.ACc text.ACc
'He stopped his anger by writing a text'

22) No objects should be implied by the reader - in contrast to examples (2ob, c) in which direct objects complement the aspectuals. On the interaction of lexical (situation type) and grammatical (viewpoint) aspect in Modern Greek, cf. Moser 1994, 1997. 
The differences between Ancient and Modern Greek ${ }^{23}$ aspectual verbs are linked to the development of participles and infinitives in Greek: ${ }^{24}$ (a) The active present participles developed into gerunds (mainly from the 14th century onwards); Modern Greek gerunds function only as adverbials, and not as complements of aspectual verbs (see Tsimpli 2000). (b) The mediopassive participles developed into adjectives (12th-14th century). (c) The infinitives were replaced by na-clauses (12th-15th century) (Moser 1997, Manolessou 2005, Joseph 1982, 1983, Karla \& Lavidas 2006).

The participles (inflected for gender, number and case) had three uses in Ancient Greek (cf. Smyth 1920[1956]: 454-479, Schwyzer 1950:387-403): complements of verbs, adjectival modifiers, and adverbials. From Late Byzantine onwards, the main function of the active present participle is adverbial, while the complement use was rare and eventually lost in Early Modern Greek. The passive participle lost the category of Voice (as it was also used with verbs that bore active endings) in the late Byzantine period, and was transformed into an adjectival category. Similarly, the loss of the infinitive in Greek took place gradually (starting from Hellenistic Greek). Verbs such as arxizo/arxazo 'start' continue to be used with an infinitive (in alternation with (i)na-clauses) as a complement (Joseph 1983), even in the last stage of the loss of the infinitive in Greek (12th-15th centuries). ${ }^{25}$

\footnotetext{
23) We should note again that we do not try to analyse Modern Greek aspectual verbs according to the Fukuda's approach, since the evidence that we presented for Ancient Greek does not concern (and cannot be applied to) Modern Greek data: there are no two groups of aspectual verbs, no long middle or passive [actually no middle voice at all], no infinitives or participles that can have the role of the complement of a verb. What we do here is to describe the differences/changes that made the search for this evidence and a parallel analysis of Modern Greek impossible.

24) We heartily thank the reviewer for his/her remarks on the restrictions on the infinitival form that is the complement of aspectual verbs in Hellenistic Greek: for example, there is a preference for arkhomai + Aorist Infinitive in Old Testament but for arkhomai + Present Infinitive in New Testament, and an option of using the PP "en + the dative case of the definite article + infinitive" (en töi basileuein auton 'he began to reign', Old Testament). We have to add that the generalisation for the verbal complements of aspectual verbs in Hellenistic Greek is as follows: pauomai + Active/Mediopassive participle, arkhomai + Active/Mediopassive infinitive. This shows a tendency for replacement of the two options of verbal complementation with only one (either only with infinitive or only with participle as it holds for the first group in Ancient Greek). Of course, the development of the infinitive (loss) and both active and mediopassive participle (change into gerund [i.e. adverbial] or mediopassive participle with adjectival behavior) in Greek did not allow them to remain as an option of verbal complementation of aspectual verbs. See also fn. 38 and the Appendix for some examples from the Hellenistic-Roman Greek period.

25) According to Joseph (1981), the uses of infinitives in Medieval Greek of 12 th-15th centuries include the complementation of aspectual verbs:
} 
To sum up, we have seen that Ancient Greek aspectual verbs fall into two groups: aspectual verbs that could select both infinitive and participial complements (and the aspectual can be in H-Asp or L-Asp) and aspectual verbs that selected a participial complement (and the aspectual must be in L-Asp). "Long middles/passives" was an option with participles, while the regular embedded middle/passive was the only option with infinitives (aspectual verb in H-Asp) [except for cases of deponent aspectual verbs]. Ancient Greek infinitives appear to be less limited than Ancient Greek participles. With regard to the development of verbal complementation of aspectuals in Greek, the development of the infinitive and the participle in Greek did not allow them to remain as an option in the verbal complementation of aspectual verbs (and all were replaced by a $n a$-clause). In the next section, we will show that Old (and Modern) English aspectual verbs share similar properties with Ancient Greek but historically different developments are attested; both Old English options were retained and later extended from Middle English into the 18th century.

\section{Aspectuals in Old and Modern English and Fukuda's Analysis}

The similar properties of the Ancient Greek and Modern English aspectual verbs historically manifest different developments. English not only retained Old English possibilities (to- vs. bare infinitives ${ }^{26}$ ), but later extended them from Middle English into the 18th century, especially in the number of tokens responding to the -ing suffixing potential (gerundives).

This means that aspectual verbs in Old English (similar to Modern English) appear to belong to two different groups with respect to the type of the complements they could take: (a) only bare infinitive or (b) both bare and to-infinitive (Callaway 1913:35-36, 40-41, 50-51, ${ }^{27}$ Los 1998).

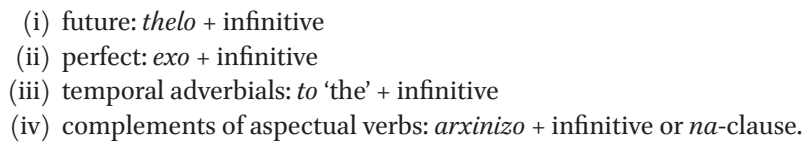

26) We follow Los (1998), according to whom the to-infinitive (a) replaced the finite subjunctive clause but not the bare infinitive, and (b) had become a full-fledged clause by the time of old English.

27) Callaway distinguishes a third group of aspectuals that take only to-infinitives. We believe that the examples of this third group do not present aspectual meanings; cf. Los 1998: 175: “... Callaway tends to gloss - and classify — his verbs according to their general meaning, not the meaning they have when followed by an infinitival complement". Callaway puts the following verbs in the third group: anforlcetan 'abandon', elcian 'delay', forwiernan 'prevent from, prohibit', gelan 'hinder from', gefon 'attempt, undertake', ieldan 'delay', onfon 'undertake', underfon 'undertake', wiernan 'desist from'. 
(i) aspectual verbs + bare infinitive

blinnan 'cease, stop'

ginnan 'begin'28

(22) a. Romane blunnun riscian on Breotene

Romans ceased attack.INF on Britain

'Romans ceased to attack Britain'

(Bede 44.2)

b. ða gunnon heo ðæt... lif ... onhyrgan

then began she the life alter.INF

'then, she began to change her life'

(ii) aspectual verbs + bare infinitive or to-infinitive ${ }^{29}$

ablinnan 'cease, desist from'

aginnan 'begin'

beginnan 'begin'

fon 'undertake, begin'

geswican 'stop, desist from'

onginnan 'begin'

(23) a. ablan his æhtan

ceased him persecute.INF

'(they) ceased to persecute him'

(Ælfric L. S. XXX 39)

$\mathrm{a}^{\prime}$. ne ablinð to asendenne bydelas

not ceases to send-forth preachers

'he does not cease to send forth preachers'

(Ælfric Hom. II 74)

b. began hine đreatigan

began him oppress.INF

'he began to oppress him'

(Wulfstan 214.24)

$\mathrm{b}^{\prime}$. beginð to healdenne

begins to hold

'he begins to hold'

(Benedict 32.1)

28) We would like to thank the anonymous reviewer who mentioned parallel developments, such as those that have to do with new causative constructions. The purpose of the paper is to deal only with the issue of the verbal complementation of aspectual verbs that is stable and includes two different verbal types in the history of English, but unstable in the history of Greek. The fact that aspectual verbs appear in causative uses in a later period both in English and Greek (Lavidas 2009), but retain the two options of complementation only in English and not in Greek, may show that the link between causativity and aspectual verbal complementation should not be considered a direct one.

29) Note that ginnan (without prefix) seems to be a L-Asp verb, but prefixed (a-, be-, on-ginnan) seems to be a H-Asp verb. A possible relation between (un)prefixed verbs and the Asp positions remains open for future study. 
c. ne geswice gebiddan

not stop command.INF

'you do not stop commanding'

(Ælfric L. S. XXXIII 206)

$c^{\prime}$. ne geswac hine to biddenne ${ }^{30}$

not stops him to worship

'he does not stop worshiping him'

(Ælfric L. S. XXXI 497)

(from Callaway 1913:40-41, 50-51)

Gerundive complements served as a replacement of the Middle English bare infinitives, which expressed semantic directedness: "since the -ing form could nicely express the actuality of an event, it is not surprising that to a certain extent the -ing form could take over the old function of the bare infinitive" (Fischer 1997:127). The option of the gerundive complement became available as a second option only when the gerundives acquired verbal properties. The gerundives descended from an Old English derivational suffix which formed abstract nouns of action (see Fanego 2004; Old English spill-ing 'destruction' < spillan), and began to acquire verbal properties from Late Middle English onwards. ${ }^{31} \mathrm{~A}$ variety of sources for the acquisition of verbal properties by the gerundives has been proposed: (a) merge of the -ing noun with the present participle (-ende); (b) productivity of the -ing noun (it became possible to form -ing nouns from any verb); (c) constructions in which an -ing noun co-occurred with a DP in genitive case (cf. Jack 1988:47); (d) influence from French; ${ }^{32}$ (e) non-availability of use of infinitives after prepositions other than to or for to. In the early stages, verbalisation was restricted to prepositional environments (She insisted on discussing the problem - Tajima 1985, Fanego 1996b, 2004, 2007), but from the middle of the 16 th century verbs with which the subject of the complement clause was co-referential with the matrix subject could take gerundives as objects (Fanego 1996a, 1996b, 2004, Jack 1988, Anderson 1993, 2004, Miller 2002: Chapter 11). Aspectual verbs (e.g. blin 'stop, cease', cease) were among the earliest verbs (besides verbs of avoidance: e.g. avoid, escape, etc.) to govern gerundives. The use of gerundives in object position spread via lexical diffusion (Fanego 1996a, Visser 1963-1973: §1775); thus, gerundive complements came to be used

\footnotetext{
30) The presence of an object does not seem to play a role in the selection of the complement; cf. $23 \mathrm{~b}$ vs. $23 \mathrm{c}$ ', hine 'him' with bare infinitive or to-infinitive.

31) Cf. Heine \& Kuteva (2007) and Heine (2009).

32) Fanego (2004) argues that the Old French gerund ending in -ant had a number of different uses, in one of which the gerund is dependent on a preposition and may govern a subject or an object: ainz soleil esconssant 'before sunset', sor mon cors deffendant 'in defending my life'.
} 
with aspectuals through a process that started with Middle English blin, cease and continuative verbs, and later extended to begin, ${ }^{33}$ start etc.

(24) from Visser 1963-1973: § 1255 ff., 1790-1792

a. thei seseden to bilde the citee

they ceased to build the city

'they stopped building the city'

b. I cesse not doynge hankyngis

Icease not do.ING thanks.Acc

'I do not stop saying thanks'

As a result of the development described, Modern English aspectual verbs ${ }^{34}$ fall into two groups: (i) aspectual verbs that can take both infinitive and gerundive complements; (ii) aspectual verbs that take only gerundive complements.

(i) aspectual verbs + infinitive or gerundive

begin, start, continue, cease

(25) a. I began/continued to write my memoires.

b. I began/continued singing at the top of my voice.

(ii) aspectual verbs + gerundive

keep on, stop, finish

(26) a. I finished reading Hamlet last night.

b. She stopped talking about them.

As we have seen, the difference in selection of these two complement types (infinitive and gerundive) in Modern English cannot be explained by the control/raising (lexical ambiguity) analysis (cf. paragraph 1), but can be analysed as a consequence of the two possible positions for aspectual verbs in terms of Fukuda (2007). Old English data (aspectual verbs with to-infinitive and bare infinitive) and Modern English data (aspectual verbs with infinitive and gerundive) - alongside the Ancient Greek data we have described in the previous paragraph — constitute morphological and syntactic evidence for the position of aspectual verbs in H-Asp or L-Asp (following Fukuda). According to this theoretical approach, aspectual verbs which can be in the H-Asp position should

33) According to Brinton (1988: 109-111) the aspectual begin could take only the bare infinitive and the infinitive with to or (in Middle English) for to up to the Middle English period. Mair (2002, 2003, 2006) assumes (following Jespersen 1940: IV, 171; V, 196, and contra Visser 1963-1973) that the aspectual begin with a verbal gerundive occurs for the first time during the late 18th century.

34) We assume that Fukuda's analysis of Modern English aspectuals is correct (see also par. 1 on Modern English). 
be able to take either of the two types of complement, that is to-infinitive and bare infinitive in Old English and to-infinitive and gerundive in Modern English, whereas aspectual verbs that are in L-Asp should take only the second type of complement, a bare infinitive (Old English) or a gerundive (Modern English).

\section{Conclusion and Further Problems}

The present article considered some parallel data from different periods of the history of Greek and English. Following Fukuda (2007) we claimed that Ancient Greek and Old English data (similar to Modern English) present a structural ambiguity between alternative syntactic positions; aspectual verbs are heads of functional projections, and can be in H-Asp, that is above vP (+ both types of the verbal complements), or in L-Asp position, that is below vP (+ only one type of the verbal complements) (see Table 1). We have seen that Ancient Greek and Old English (and Modern English) aspectual verbs fall into two groups: (i) aspectual verbs that could select both infinitive/to-infinitive and participial/bare infinitive complements; (ii) aspectual verbs that selected only a participial/bare infinitive complement. Furthermore, "long middles/passives" are an option with aspectual verbs that can be in L-Asp while the regular embedded middle/passive is the only option with an aspectual verb in H-Asp. Ancient Greek infinitives are selected by aspectuals in H-Asp since they appear to be less limited than participles. On the other hand, we have seen that the similar properties of the Ancient Greek and Modern English aspectual verbs historically manifest different developments, since English extended Old English possibilities, from Middle English into the 18th century. The development of the infinitive (loss) and both of the active and mediopassive participle (showing the change into gerunds [i.e. adverbials] or participles with adjectival behavior that cannot have the role of complement of verbs, respectively) in Greek ${ }^{35}$ did not allow them to remain as an option of verbal complementation of aspectual verbs.

\footnotetext{
35) We agree with the reviewer who mentioned that different complements with the same predicate appear in Modern Greek as well, not with aspectuals but with verbs such as ksero know na/oti how to/that (den ksero an not know if). We would also agree with the reviewer that in these cases (Modern Greek nonaspectuals), depending on the complement, the selecting predicate may acquire a different meaning through the interaction between the lexical semantics of the verb and the properties of the complementizer or the na particle. See also Roussou (2006, 2010).
} 
Table 1. Aspectual verb complementation in Ancient Greek and Old and Modern ${ }^{36}$ English.

\begin{tabular}{lll}
\hline Greek Aspectual Verbs & & \\
Ancient Greek & (a)+Infinitive /+Participle & $\rightarrow$ H-Asp or L-Asp \\
& (b) +Participle & $\rightarrow$ L-Asp \\
\hline English Aspectual Verbs & & \\
Old English & $($ a $)+$ to-infinitive / bare-Infinitive & $\rightarrow$ H-Asp or L-Asp \\
& $($ b $)$ +bare Infinitive & $\rightarrow$-Asp \\
Modern English & $($ a $)+$ to-infinitive / +Gerundive & $\rightarrow$ H-Asp or L-Asp \\
& $(b)+$ Gerundive & $\rightarrow$-Asp \\
\hline
\end{tabular}

\section{Open Questions}

Structural ambiguity has been shown to lead to diachronic reanalysis. Lightfoot $(1979,1999)$ has developed the reanalysis-through-ambiguity argument: the precondition of a diachronic reanalysis is a structural/formal ambiguity of the affected type accessible to the learner. Ancient Greek and English aspectual verbs are ambiguous between H-Asp and L-Asp functional heads; hence, it would be reasonable to think that reanalysis is involved in the development of aspectual verbs. What we observe, however, is that disambiguation and transparency cannot be considered as having led to the specific changes with regard to aspectual verbs. In both English and Greek, older types (Greek infinitives and participles, English bare infinitives) are replaced ${ }^{38}$ by newer types (Greek

36) For Modern English, on the basis of Fukuda (2007).

37) We do not present an analysis (or diagnostics) for Modern Greek in the present paper, since there is no relative overt morpho-syntactic evidence for aspectuals in Modern Greek (due to the loss of the infinitives and the fact that participles changed to gerunds which have an adverbial behavior and to "new" mediopassive participles which have an adjectival behavior). Of course, it is obvious that two hypotheses can be stated since ambiguity carries over into Modern Greek aspectual verbs: change or continuation/replacement. A first alternative would be that an important change occurred (from a structural ambiguity to a lexical one [raising and control analysis]) and Greek changed entirely in this aspect. According to the second alternative, we may have continuation of the structural ambiguity - as in English — but only of the group of aspectuals that have both H-Asp and L-Asp options.

38) Grammaticalisation does not account for the specific change since there is no reason to believe that $n a$-complements in Greek as opposed to infinitives are somehow more abstract or bonded or bleached or morphologically reduced (M-reduced) or phonetically eroded (cf. Roberts \& Roussou 2003: 80). Furthermore, we do not follow the broader view of grammaticalisation, according to which the structures emerging from verbal complementation may also be considered part of grammaticalisation (Hopper \& Traugott 2003: 176, Givón 2009; and for a detailed discussion, cf. Cuyckens 2010). The diachrony of Greek provides a counter-example to the broader view of grammaticalisation and, mainly, to the unidirectionality path in verbal complementation ("one and the same item undergoes a particular development", Cuyskens 2010). na-clauses do not show reduc- 
$n a$-clauses, English verbal gerundives) for reasons that seem to have nothing to do with the ambiguity of the aspectual verbs (but with changes in the categories of the complements: the category of bare infinitives in English, the category of infinitives in Greek). Replacement ${ }^{39}$ probably occurs because of perceived similarity of patterns (semantic overlap and same structural possibilities; cf. the replacement of that-clauses with verbs of volition by the to-infinitive; Los 2005, Fischer 2007:221, Cuyckens 2010). The replacement does not lead to loss of ambiguity, since the ambiguity (structural or lexical) is retained after the replacement of the Greek infinitives and participles (by na-clauses) and the English bare infinitives (by gerundives). With regard to the stability in ambiguity, recall that the "new" na-clauses with aspectual verbs in Greek have been considered ambiguous between control and raising predicates (Drachman 1989, Alexiadou \& Anagnostopoulou 1999, Tapio 2003). It seems that in the case of the aspectual verbs in the diachrony of Greek and English, we have an example of retention of ambiguity through replacement: ${ }^{40}$ (i) the Greek infinitives are replaced by the $n a$-clause, but the ambiguity is retained (in the form of H-Asp and L-Asp positions) or through an ambiguity of a different (lexical ambiguity) type (raising/control); (ii) in English, there is no infinitive loss, but the new gerundives replace the bare infinitives (in their function as complements of aspectuals), and aspectual verbs emerge that can take both infinitives and gerundives as complements.

Of course, the discussion of the data opens even more issues: For example, (a) why do we observe a position-parallel between raising/control constructions and aspectuals? It is only relative; if there is a behavioral difference, then is there a structural one(?); (b) what is the role of a DP-complement with aspectual verbs? Under coercion of a DP to an event (Pustejovsky 1995a, 1995b), we interpret:

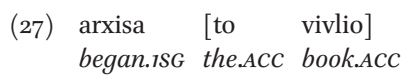

as:

tion in tense-aspect morphology or a more unified/bonded clause combining if we compare them with the Ancient Greek infinitives and participles.

39) Note that we do not identify replacement with competition, but we use the term replacement as in the relevant replacement theory bibliography (Los 2005, Fischer 2007: 221, Cuyckens 2010). Since the aim of the present paper is not to discuss replacement in verbal complementation-but to discuss similar patterns of verbal complementation in Ancient Greek, Old (and Modern) English under the perspective of Fukuda, we do not examine relevant quantitative data and leave that subject open for future research.

40) We expect that this relation is more broad than shown in the specific examples here, in other words, we expect that many cases of replacement in diachrony can be linked to retention of this type of structural ambiguity; we leave this issue open for future research. 


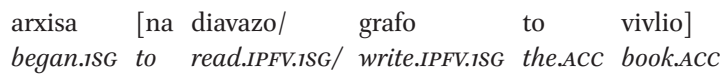

'I began to read/write the book'

(c) should the infinitive loss and its relation with the aspectuals be put in the wider context, e.g. the context of Balkan linguistics (cf. Joseph 1982, 1983)? (d) is there a correlation between verbal and complement-types across languages (similar to the one observed in Old, Modern English and Ancient Greek) or families of languages (Indo-European and beyond)?

\section{References}

Agouraki, Georgia. 1991. A Modern Greek complementizer and its significance for Universal Grammar. UCL Working Papers in Linguistics 3: 1-24.

Akmajian, Adrian, Susan M. Steele and Thomas Wasow. 1979. The category AUX in Universal Grammar. Linguistic Inquiry 10: 1-64.

Alexiadou, Artemis and Elena Anagnostopoulou. 1999. Raising without infinitives and the nature of Agreement. Proceedings of the West Coast Conference on Formal Linguistics 18, 14-26. Somerville, CA: Cascadilla Press.

Anderson, John. 1993. Parameters of syntactic change: a notional view. In Charles Jones (ed.), Historical Linguistics: Problems and Perspectives, 1-42. London: Longman.

Anderson, John. 2004. Syntactic categories and syntactic change: the development of subjunctive periphrases in English. In Isabel Moskowich-Spiegel Fandiño and Begoña Crespo Garcia (eds.), New Trends in English Historical Linguistics: an Atlantic View, 31-73. Coruña: Universidade da Coruña.

Arregi, Karlos and Gainko Molina-Azaola. 2004. Restructuring in Basque and the theory of agreement. WCCFL 23: 101-114.

Bolinger, Dwight. 1968. Entailment and the meaning of structures. Glossa 2: 119-127.

Borer, Hagit. 1994. The projection of arguments. In Elena Benedicto and Jeff Runner (eds.), Functional Projections: University of Massachusetts Occasional Papers 17: 19-48. Amherst: University of Massachusetts.

Borer, Hagit. 1998. Deriving passive without theta roles. In Steven Lapointe, Dian Brentari and Patrick Farrell (eds.), Morphology and its Relation to Phonology and Syntax, 6o-99. Stanford: CSLI.

Borer, Hagit. 2005. Structuring Sense. Volume II: the Normal course of Events. Oxford: Oxford University Press.

Brinton, Laurel J. 1988. The Development of English Aspectual Systems: Aspectualizers and Postverbal Particles (Cambridge Studies in Linguistics, 49). Cambridge: Cambridge University Press.

Callaway, Morgan. 1913. The Infinitive in Anglo-Saxon. Washington: Carnegie Institute of Washington.

Chomsky, Noam. 1995. The Minimalist Program. Cambridge, Mass: MIT Press.

Cinque, Guglielmo. 2003. The interaction of passive, causative, and 'restructuring' in Romance. In Christina Tortora (ed.), The Syntax of Italian Dialects. Oxford: Oxford University Press.

Cuyckens, Hubert. 2010. Verb complementation and grammaticalization in the history of English. Paper presented at Societas Linguistica Europaea 2010, 1 September 2010, Vilnius, Lithuania.

Drachman, Gaberell. 1989. Raising in a language without infinitives. Paper for All-Austria Linguistics Meeting, Vienna. Unpublished manuscript, University of Salzburg.

Drachman, Gaberell. 2008. Meaning variation and change in Morphology. In Nikolaos Lavidas, Elissavet Nouchoutidou and Marietta Sionti (eds.), New Perspectives in Greek Linguistics, 1-34. Newcastle: Cambridge Scholars Publishing. 
Fanego, Teresa. 1996a. The development of gerunds as objects of subject-control verbs in English (1400-1760). Diachronica 13: 29-62.

Fanego, Teresa. 1996b. The gerund in Early Modern English: evidence from the Helsinki Corpus. Folia Linguistica Historica 17: 97-152.

Fanego, Teresa. 2004. On reanalysis and actualization in syntactic change: the rise and development of English verbal gerunds. Diachronica 21: 5-55.

Fanego, Teresa. 2007. Drift and the development of sentential complements in British and American English from 1700 to the present day. In Javier Pérez-Guerra, Dolores González-Álvarez, Jorge L. Bueno-Alonso and Esperanza Rama-Martínez (eds.). "Of varying language and opposing creed": New Insights into Late Modern English (Linguistic Insights Series 28), 161-235. Bern: Peter Lang.

Fischer, Olga. 1997. The grammaticalisation of infinitival to in English compared with German and Dutch. In Raymond Hickey and Stanislaw Puppel (eds.), Language History and Linguistic Modelling. A Festschrift for Jacek Fisiak on his 6oth birthday, volume I, 265-280. Berlin: Mouton de Gruyter.

Fischer, Olga. 2007. Morphosyntactic Change: Functional and Formal Perspectives. Oxford: Oxford University Press.

Freed, Alice. 1979. The Semantics of English Aspectual Complementation. Dordrecht: Reidel.

Fukuda, Shin. 2006. The syntax of Japanese aspectual verbs. Paper presented at the $3 r d$ Workshop on Altaic in Formal Linguistics.

Fukuda, Shin. 2007. On the control/raising ambiguity with aspectual verbs: a structural account. In Barbara Stiebels (ed.), ZAS Papers in Linguistics 47: Studies in Complement Control, 159-195. Berlin: ZAS.

Fukuda, Shin. 2008. Two syntactic positions for English aspectual verbs. In Charles B. Chang and Hannah J. Haynie (eds.), Proceedings of the 26th West Coast Conference on Formal Linguistics, 172-180. Somerville, MA: Cascadilla Proceedings Project.

Giannakidou, Anastasia. 1998. Polarity Sensitivity as (Non)Veridical Dependency. Amsterdam: John Benjamins.

Gildersleeve, Basil L. 190o. Syntax of Classical Greek from Homer to Demosthenes. New York: American Book Company.

Givón, Talmy. 2009. Multiple routes to clause union: the diachrony of complex verb phrases. In Talmy Givón and Masayoshi Shibatani (eds.), Syntactic Complexity: Diachrony, Acquisition, Neuro-Cognition, Evolution, 81-118. Amsterdam: John Benjamins.

Goodwin, William W. 1894 [1978]. A Greek Grammar. London: St. Martin's Press [reprint of 1894 edition].

Heine, Bernd. 2009. From nominal to clausal morphosyntax: complexity via expansion. In Talmy Givón and Masayoshi Shibatani (eds.), Syntactic Complexity: Diachrony, Acquisition, NeuroCognition, Evolution, 23-52. Amsterdam: John Benjamins.

Heine, Bernd and Tania Kuteva. 2007. The Origins of Grammar. Cambridge: Cambridge University Press.

Hopper, Paul J. and Elizabeth Closs Traugott. 2003. Grammaticalization (2nd Edition). Cambridge: Cambridge University Press.

Hornstein, Norbert. 2003. On control. In Randall Hendrick (ed.), Minimalism Syntax, 6-81. Oxford: Blackwell.

Humbert, Jean. 1945. Syntaxe Grecque. Paris: Librairie Klincksieck.

Jack, George. 1988. The origins of the English gerund. NOWELE 12: 15-75.

Jannaris, Antonius. 1897 [1968]. An Historical Greek Grammar. London: MacMillan. (Reprint 1987, Hildesheim: Georg Olms).

Jespersen, Otto. 1940. A Modern English Grammar on Historical Principles. London: George Allan and Unwin.

Joseph, Brian. 1981. On the synchrony and diachrony of Modern Greek na. Byzantine and Modern Greek Studies 7: 139-154. 
Joseph, Brian. 1982. A new convergence concerning the Balkan loss of the infinitive. Indogermanische Forschungen 85: 176-187.

Joseph, Brian. 1983. The Synchrony and Diachrony of the Balkan Infinitive: a Study in Areal, General, and Historical Linguistics. Cambridge: Cambridge University Press.

Joseph, Brian. 2001. Ancient Greek. In Jane Garry and Carl Rubino (eds.), Facts about the World's Languages. An Encyclopedia of the World's Major Languages: Past and Present. New York/Dublin: H.W. Wilson Press.

Karla, Grammatiki and Nikolaos Lavidas. 2006. To aparemfato ston aksona tis diaxronias tis Elinikis [The infinitive in the diachrony of Greek]. Proceedings of ICGL-6. CD-Rom and [http://www .philology.uoc.gr/conferences/6thICGL/ebook]

Kiparsky, Paul. 2003. Accent, syllable structure, and morphology in Ancient Greek. In Elizabeth Mela Athanasopoulou (ed.), Selected Papers from the 15th International Symposium on Theoretical and Applied Linguistics, 81-106. Thessaloniki.

Kratzer, Angelika. 1994. On external arguments. In Elena Benedicto and Jeffery Runner (eds.), Functional Projections: University of Massachusetts Occasional Papers 17, 103-130. Amherst, MA: GLSA.

Kratzer, Angelika. 1996. Severing the external argument from the verb. In Johan Rooryck and Laurie Zariing (eds.), Phrase Structure and the Lexicon, 109-137. Dordrecht: Kluwer.

Kühner, Raphael and Bernhard Gerth. 1898-1904 [1963]. Ausführliche Grammatik der Griechischen Sprache. Zweiter Teil: Satzlehre. Hannover and Leipzig: Hannsche Buchhandlung.

Landau, Idan. 2004. The scale of finiteness and the calculus of control. Natural Language and Linguistic Theory 22: 811-877.

Lavidas, Nikolaos. 2009. Transitivity Alternations in Diachrony. Changes in Argument Structure and Voice Morphology. Newcastle: Cambridge Scholars Publishing.

Liddell, Henry George, Robert Scott, Henry Stuart Jones and Roderick McKenzie. 1996. A GreekEnglish Lexicon (\& Supplement). Oxford: Oxford University Press.

Lightfoot, David W. 1979. Principles of Diachronic Syntax. Cambridge: Cambridge University Press.

Lightfoot, David W. 1999. The Development of Language: Acquisition, Change and Evolution. Oxford: Blackwell.

Los, Bettelou. 1998. The rise of the to-infinitive as verb complement. English Language and Linguistics $2: 1-36$.

Los, Bettelou. 2005. The Rise of the to-infinitive. Oxford: Oxford University Press.

Mair, Christian. 2002. Three changing patterns of verb complementation in Late Modern English: a real-time study based on matching text corpora. English Language and Linguistics 6: 105131.

Mair, Christian. 2003. Gerundial complements after begin and start: grammatical and sociolinguistic factors, and how they work against each other. In Günter Rohdenburg and Britta Mondorf (eds.), Determinants of Grammatical Variation in English, 329-345. Berlin: Mouton de Gruyter.

Mair, Christian. 2006. The 19th century as a critical period in the formation of the Modern English system of non-finite complement clauses: the case of remember. In Merja Kytö, Mats Rydén and Erik Smitterberg (eds.). Nineteenth Century English: Stability and Change, 215-228. Cambridge: Cambridge University Press.

Manolessou, Io. 2005. From participles to gerunds. In Melita Stavrou and Arhonto Terzi (eds.), Advances in Greek Generative Syntax, 241-283. Amsterdam: Benjamins.

Marantz, Alec. 2001. Words (unpublished ms.) MIT.

Martin, Roger. 2001. Null case and the distribution of PRO. Linguistic Inquiry 32: 141-166.

Meillet, Antoine and Joseph Vendryes. 1924. Traité de grammaire comparée des langues classiques. Paris: Champion.

Miller, D. Gary. 2002. Non-finite Structures in Theory and Change. Oxford: Oxford University Press.

Moser, Amalia. 1994. The interaction of lexical and grammatical aspect in Modern Greek. In Irene Philippaki-Warburton, Katerina Nicolaidis and Maria Sifianou (eds.), Themes in Greek Linguis- 
tics: Papers from the First International Conference on Greek Linguistics, Reading, September 1993, 137-144. Amsterdam: John Benjamins.

Moser, Amalia. 1997. The choice of aspect in na-complements. In Gaberell Drachman, Angeliki Malikouti-Drachman, Jannis Fykias and Sila Klidi (eds.), Greek Linguistics '95: Proceedings of the 2nd International Conference on Greek Linguistics, 567-576. Graz: Neugebauer.

Perlmutter, David M. 1968. Deep and Surface Structure Constraints in Syntax. PhD Dissertation, MIT.

Perlmutter, David M. 1970. The two verbs begin. In Roderick Jacobs and Peter Rosenbaum (eds.), Readings in English Transformational Grammar, 107-119. Waltham: Blaisdell Publishing Company.

Philippaki-Warburton, Irene. 1985. Word order in Modern Greek. Transactions of the Philological Society 7: 113-143.

Philippaki-Warburton, Irene. 1993. The subjunctive mood and the syntactic status of the particle na in Modern Greek. Folia Linguistica 28 (3-4): 297-326.

Philippaki-Warburton, Irene. 1998. Functional categories and Modern Greek syntax. The Linguistic Review 15: 159-186.

Philippaki-Warburton, Irene and Ioannis Veloudis. 1984. The subjunctive in complement clauses. Studies in Greek Linguistics 5: 87-104.

Pustejovsky, James. 1995a. The Generative Lexicon. Cambridge: MIT Press.

Pustejovsky, James. 1995b. Linguistic constraints on type coercion. In Patrick Saint-Dizier and Evelyn Viegas (eds.), Computational Lexical Semantics, 71-97. Cambridge: Cambridge University Press.

Roberts, Ian and Anna Roussou. 2003. Syntactic Change. A Minimalist Approach to Grammaticalization. Cambridge: Cambridge University Press.

Roussou, Anna. 2000. On the left periphery: modal particles and complementisers. Journal of Greek Linguistics 1: 65-94.

Roussou, Anna. 2006. Simpliromatiki diktes [Complementizers]. Athens: Patakis.

Roussou, Anna. 2010. Selecting complementizers. Lingua 120: 582-603.

Sevdali, Christina. 2007. Infinitival Clauses in Ancient Greek: Overt and Null Subjects, the Role of Case and Focus. PhD Dissertation, University of Cambridge.

Schwyzer, Eduard. 1950. Griechische Grammatik (volume II). München: Beck.

Smyth, Herbert. 1920 [1956]. Greek Grammar. Cambridge, MA: Harvard University Press.

Stahl, Johann M. 1907. Kritisch-historische Syntax des griechischen Verbums der klassischen Zeit. Heidelberg: Winter.

Tajima, Matsuji. 1985. The Syntactic Development of the Gerund in Middle English. Tokyo: Nan'un-do. Tapio, Sophia. 2003. Obligatory control and raising in Modern Greek subjunctive complements. In Stephen Grimes and Ken de Jong (eds.), IULC Working Papers Online 3. [https://www.indiana .edu/ iulcwp/pdfs/o3-tapioo6new.pdf]

Terzi, Arhonto. 1997. PRO and null Case in finite clauses. The Linguistic Review 14: 335-360.

Travis, Lisa. 1991. Inner aspect and the structure of VP. Cahiers de Linguistique de l'UQAM 1:132-146.

Tsimpli, Ianthi Maria. 1990. Clause structure and word order in Modern Greek. UCL Working Papers in Linguistics 2: 226-255.

Tsimpli, Ianthi Maria. 2000. Gerunds in Greek. Journal of Greek Linguistics 1: 133-169.

Tsoulas, George. 1993. Remarks on the structure and interpretation of na-clauses. Studies in Greek Linguistics 14: 191-206.

Tsoulas, George. 1994. Subjunctives as indefinites. In Gianluigi Borgato (ed.), Teoria del Linguaggio e Analisi Linguistica: XX Incontro di Grammatica Generativa, 387-407. Padua: Unipress.

Visser, Frederikus Th. 1963-1973. An Historical Syntax of the English Language. Leiden: E.J. Brill.

Woodhouse, S.C. 1910. English-Greek Dictionary: a Vocabulary of the Attic Language. London: George Routledge and Sons.

Wurmbrand, Susi. 2001. Infinitives: Restructuring and Clause Structure. Berlin: Mouton de Gruyter. 


\section{Appendix}

\section{A. Verbal Complements of pauō/pauomai}

Ancient Greek examples of pauō/pauomai (from TLG online); most examples consist of mediopassive pauomai + participle:

a. Mediopassive + Participle

phasi Persai tous Hellēnas siteomenous peinōntas pauesthai

say Persians the.ACC Greeks.ACC eat.PTCP.MP.ACC.PL be-hungry stop.INF.MP

'the Persians say of Greeks that they stop eating while still hungry' (Herodotus, 1, 133, 7-8)

b. Mediopassive + Participle

hōs mēdepote pauōntai harmozontes epi ksenēs

that never stop.MP.3PL govern.PTCP.ACT.NOM.PL in foreign-land

'that they never stop governing in a foreign land'

(Xenophon, De republica Lacedaemoniorum, 14, 4)

c. Mediopassive + Participle

heōs an pausōntai tōn hēmeterōn amphisbētountes

until PRT stop.AOR.SUBJ.MID. $3^{P L}$ the ours lay-claim.PTCP.ACT.NOM.PL

'until they cease from laying claim to what is ours' (Isocrates, Archidamus, 74, 7)

d. Mediopassive + Participle

hotan mentoi odunōmenoi pausōntai

when PRT pain.PTCP.MP.NOM.PL stop.AOR.SUBJ.MID.3PL

'but when they cease to have pain' $\quad$ (Hippocrates, De articulis, 12, 16)

e. Mediopassive + Participle

ouden pauometha eis to auto aei peripheromenoi

not stop.MP.1PL to the same always circle.PTCP.MP.NOM.PL

'we have never ceased circling round to the same point' (Plato, Gorgias, 517c, 6)

f. Mediopassive + Participle

to men opson ouk epausato esthiōn

the PRT meat not stopped.MID.3SG eat.PTCP.ACT.NOM.SG

'he did not stop eating his meat'

(Xenophon, Memorabilia, 3, 14, 4)

g. Mediopassive + Participle

epausato poreuomenos, apekhōn eis triakonta stadious

stopped.MID.3SG walk.PTCP.MP.NOM.SG be-at-distance of thirty stadia

'he stopped walking, while still at a distance of about thirty stadia'

(Xenophon, Anabasis, 4, 6, 6)

h. Mediopassive + Participle

dio ekeinos te proteron kai Dareios husteron epausato

cONJ he and first and Darius afterwards stopped.MID.3SG

dioruttōn

make-canal.PTCP.ACT.NOM.SG

'so he first, and Darius afterwards, stopped making the canal'

(Aristoteles, Meteorologica, 352b, 29) 
i. $\quad$ Mediopassive + Participle

hoi ksumpantes epausanto en orgēi ekhontes...

the altogether stopped.MID.3PL in anger have.PTCP.ACT.NOM.PL ...

'And altogether, they stopped being angry' (Thucydides, Historiae, 2, 65, 3)

j. $\quad$ Mediopassive + Participle

hoi mentoi polemioi ouden epausanto di' holēs tēs nuktos

the PRT enemies not stopped.MID.3PL through all the night

kulindontes tous lithous

roll.PTCP.ACT.NOM.PL the stones

'The enemy, however, never stopped rolling down their stones all through the night'

(Xenophon, Anabasis, 4, 2, 4)

k. Mediopassive + Participle

tēi patridi mou ou prosthen epausanto polemountes

the native-state my not before stopped.MID.3PL wage-war.PTCP.ACT.NOM.PL

'(the Lacedaemonians) did not cease waging war upon my native state'

(Xenophon, Anabasis, 6, 1, 27)

1. Active + Infinitive

epause en Sikuōni agōnizesthai tōn Homēreiōn epeōn heineka stopped.Act.3sG at Sicyon contend.INF.MP the Homeric poems because-of

'(Cleisthenes) made an end of contests at Sicyon by reason of the Homeric poems'

(Herodotus, 5, 67, 1)

m. Active + Infinitive

hē min pausei katastrepsasthai tēn Eurōpēn

which him stop.Act.3sg subdue.INF.MID the Europe

'which would keep him from subduing Europe'

(Herodotus, 7, 54, 7-8)

n. Active + Participle

epausan phoboumenous plēthos neōn te kai andrōn

stopped.ACT.3PL fear.PTCP.MP.ACC.PL multitudes ships and and men

'they stopped being afraid of the multitudes of ships and men' (Plato, Menexenus, 241b, 6)

\section{Post-Classical Greek: New Testament Greek}

\section{Mediopassive + Active/Mediopassive Participle}

a. ap' hēs hēmeras ēkousamen, ou pauometha huper humōn from which day heard stop.MP.IPL for you

proseukhomenoi kai aitoumenoi pray.PTCP.MP.NOM.PL and request.PTCP.MP.NOM.PL

'since the day we heard this, we do not cease praying and making requests for you'

(Novum Testamentum, Epistula Pauli ad Colossenses, 1, 9, 1)

b. ouk an epausanto prospheromenai

not PRT stopped.MID.3PL offer.PTCP.MP.NOM.PL

'they would not have ceased to be offered'

(Novum Testamentum, Epistula Pauli ad Hebraeos, 10, 2, 2) 
c. ho anthrōpos houtos ou pauetai lalōn rhēmata kata ... the man this not stop.MP.3SG speak.PTCP.ACT.NOM.SG words against 'This man never stops speaking words against ...'

(Novum Testamentum, Acta apostolorum, 6, 13, 2)

d. ou pauomai eukharistōn huper humōn

not stop.MP.ISG thank.PTCP.ACT.NOM.SG for you

'I do not cease to give thanks for you'

(Novum Testamentum, Epistula Pauli ad Ephesios, 1, 16, 1)

e. ouk epauonto kai euangelizomenoi tidaskontes Khriston, not stopped.MP.3PL teach.PTCP.ACT.NOM.PL and preach.PTCP.MP.NOM.PL the Christ,

Iēsoun

Jesus

'they never stopped teaching and preaching Jesus, the Christ.'

(Novum Testamentum, Acta apostolorum, 5, 42, 2)

\section{B. Verbal Complements of arkhō/arkhomai}

Ancient Greek examples of arkhö/arkhomai (from TLG online); most examples consist of mediopassive arkhomai (deponent with the meaning 'begin' in Classical Greek) + mediopassive participle:

a. Mediopassive + Mediopassive Participle

ērkhometha dialegomenoi, hina ...

began.MP.1PL converse.PTCP.MP.NOM.PL to

'we began our conversation in order to ...'

(Plato, Theaetetus, 187a, 1)

b. Mediopassive + Mediopassive Participle

kai arkhōmetha enteuthen bouleuomenoi, hōs...

and begin.MP.1PL hence discuss.PTCP.MP.NOM.PL that

'and let us take as the starting point of our discussion the assumption' （Plato, Crito, 49d,6)

c. Mediopassive + Active Infinitive

kai gar melopoiein arkhetai

and PRT compose.INF.ACT $\overline{\text { begin.MP.3SG }}$

'He has started to compose'

(Aristophanes, Thesmophoriazusae, 67)

d. Mediopassive + Mediopassive Infinitive

hothen arkhetai mimeisthai ho mimoumenos?

from-which begin.MP.3SG imitate.INF.MP the imitator

'with which the imitator begins his imitation?'

(Plato, Cratylus, 424b, 8)

e. Mediopassive + Active Participle

arksomai didaskōn ek tōn theiōn

begin.MID.ISG teach.PTCP.ACT.NOM.SG from the divine

'I will begin teaching with things divine'

(Xenophon, Cyropaedia, 8, 8, 2) 
f. Active + Active Infinitive (only in Homeric Greek)

arkhete nun nekuas phoreein

begin.ACT.2PL now dead-bodies wear.INF.ACT

'Begin now to wear the dead bodies'

(Homer, Odyssey, 22, 437)

g. Active + Mediopassive Infinitive (only in Homeric Greek)

ērkhe neesthai

began.ACT.3SG leave.INF.MP

'he led the way departing (from the council)'

(Homer, Iliad, 2, 84)

h. Active + Active Participle (only in Homeric Greek)

ērkhon khalepainōn

began.ACT.ISG be-angry.PTCP.ACT.NOM.SG

'I was the first to be angry / and it was I that waxed wroth the first' $\quad$ (Homer, Iliad, 2, 378)

\section{Post-Classical Greek: New Testament Greek}

\section{Mediopassive + Active/Mediopassive Infinitive}

a. apo tote $\underline{\text { erksato }}$ ho Iēsous kērussein kai legein ...

from then started.MID.3SG the Jesus preach.INF.ACT and say.INF.ACT

'From that time, Jesus began to preach, and to say ...'

(Novum Testamentum, Evangelium secundum Matthaeum, 4, 17, 1)

b. $\underline{\text { erksato }} \underline{\text { lupeisthai }}$ kai adēmonein.

started.MID.3SG grieve.INF.MP and be-severely-troubled.INF.ACT

'and began to be sorrowful and severely troubled.'

(Novum Testamentum, Evangelium secundum Matthaeum, 26, 37, 2)

c. Kai palin ērksato didaskein para tēn thalassan.

and again started.MID.3SG teach.INF.ACT by the sea

'Again he began to teach by the seaside.'

(Novum Testamentum, Evangelium secundum Marcum, 4, 1, 1)

d. ho okhlos ērksato aiteisthai kathōs epoiei autois.

the crowd started.MID.3SG ask.INF.MP as do them

'The crowd began to ask him to do as he always did for them.'

(Novum Testamentum, Evangelium secundum Marcum, 15, 8, 1) 